ORIGINAL ARTICLE

\title{
Reduction of seminal plasma concentration can decrease detrimental effects of seminal plasma on chilled ram spermatozoa
}

\author{
Reza Rajabi-Toustani1,2* (D), Mohammad Roostaei-Ali Mehr (D), Rasool Motamedi-Mojdehi (D) \\ ${ }^{1}$ Department of Animal Science, Faculty of Agricultural Sciences, University of Guilan, Rasht, Iran \\ ${ }^{2}$ Department of Clinical Veterinary Science, Obihiro University of Agriculture \& Veterinary Medicine, Obihiro, Hokkaido, Japan
}

How to cite: Rajabi-Toustani R, Mehr R.M, Motamedi-Mojdehi R. Reduction of seminal plasma concentration can decrease detrimental effects of seminal plasma on chilled ram spermatozoa. Anim Reprod. 2021;18(1):e20200211. https://doi.org/10.1590/1984-3143-AR2020-0211

\begin{abstract}
This study was conducted to investigate the effect of different levels of seminal plasma (SP) and cold-shock on ram spermatozoa during $36 \mathrm{~h}$ storage at $5^{\circ} \mathrm{C}$. In both ejaculated spermatozoa coated with egg yolk (second ejaculate; coated spermatozoa) and epididymal spermatozoa, samples were treated with 0, 50 and $100 \%$ seminal plasma. Different levels of seminal plasma were added on the basis of ram spermatocrit (32\%). Then half of aliquots were suddenly put on ice water (cold-shock) and other half were gradually $\left(0.25^{\circ} \mathrm{C} / \mathrm{min}\right)$ chilled (non- cold shock). Sperm motility, viability and functional membrane integrity were determined in both aliquots at $0,12,24$ and $36 \mathrm{~h}$ storage at $5^{\circ} \mathrm{C}$. Under non- cold shock and cold-shock conditions, coated spermatozoa treated with $0 \%$ SP showed the highest motility compared to ejaculated spermatozoa (first ejaculate; uncoated spermatozoa) after 12,24 and $36 \mathrm{~h}$ of storage at $5^{\circ} \mathrm{C}(P<0.05)$. Under non- cold shock and cold-shock conditions, viability and functional membrane integrity was higher in the coated spermatozoa treated with $0 \%$ SP than in the uncoated spermatozoa during $36 \mathrm{~h}$ storage $(P<0.05)$. There was no significant difference between coated spermatozoa treated with 0 and $50 \%$ SP in the percentage of motility and viability after 24 and $36 \mathrm{~h}$ of storage $(P>0.05)$. Under non- cold shock and cold-shock conditions, the percentage of motility of epididymal spermatozoa treated with $0 \%$ SP was significantly $(P<0.05)$ higher than those treated with $100 \% \mathrm{SP}$ after $36 \mathrm{~h}$ of storage at $5^{\circ} \mathrm{C}$. In conclusion, removal of seminal plasma and/or reduction (up to 50\%) of its concentration can decrease detrimental effects of seminal plasma on chilled ram spermatozoa.
\end{abstract}

Keywords: coated spermatozoa, cold-shock, ram spermatozoa, seminal plasma.

\section{Introduction}

Ram spermatozoa are more sensitive to cold-shock stress than those of other species (Muiño-Blanco et al., 2008). The fertility of liquid stored ram semen following cervical Al rapidly decreases if stored beyond 12-24 h (Maxwell and Salamon, 1993), while acceptable fertility with frozen-thawed ram semen can only be achieved by the use of intrauterine Al (facilitated commercially by laparoscopy; Killen and Caffery, 1982; Maxwell et al., 1984). Therefore, the ability to extend the period of maximum fertility when liquid stored ram semen is used would be of great benefit.

Seminal fluid is a complex medium containing a great variety of molecules, produced by testes, epididymides, sex accessory glands and also cells (apart from spermatozoa) that have many potential effects on both male and female fitness (e.g. sperm capacitation, sperm competition and fertilisation for male, and food, immunostimulation and antibiotic effects for

*Corresponding author: rezarajabi.t@gmail.com

Received: October 22, 2020. Accepted: April 10, 2021.

Financial support: None.

Conflicts of interest: The authors have no conflict of interest to declare.

(c) (i) Copyright (c) The Author(s). This is an Open Access article distributed under the terms of the Creative Commons Attribution License, which permits unrestricted use, distribution, and reproduction in any medium, provided the original work is properly cited. 
female) (Poiani, 2006). Seminal plasma (SP) can be detrimental to bull and stallion liquid sperm storage (Bergeron et al., 2004; Way and Killian, 2002) or cryopreservation (Martinus et al., 1991; Moore et al., 2005).

Bovine seminal plasma (BSP) protein family binds to sperm membrane choline phospholipids upon ejaculation and stimulates cholesterol and phospholipid efflux from the sperm membrane. In the female reproductive tract, sperm-bound BSP proteins interact with oviductal/follicular fluid components (such as high-density lipoproteins; HDL) and stimulate a second cholesterol efflux, resulting in capacitation (Manjunath and Thérien, 2002). Long exposure of sperm to these proteins or exposure to high concentrations of them could be deleterious to the sperm membrane.

In domestic species, fast cooling from 30 to $0^{\circ} \mathrm{C}$ causes cell injury in some sperm cells called "cold-shock" that is dependent on the cooling rate and temperature interval (Gilmore et al., 1998; Watson, 2000) and produces an irreversible loss of motility and a disruption of acrosomes and membranes (Kawano et al., 2004).

On the other hand, the discovery that egg yolk has a beneficial effect on fertility of semen (Phillips and Lardy, 1940) led to its widespread use in bull semen extenders. Early researchers reported that egg yolk aids the bull (Lasley and Mayer, 1944) and stallion (Bogart and Mayer, 1950) sperm cell in resisting cold-shock. Also low-density lipoprotein (LDL) would promote the entry of phospholipids and cholesterol into the cell membrane (Bergeron et al., 2004) and build a complex with seminal plasma proteins, making them unavailable to function in the membrane (Bergeron et al., 2004; Manjunath et al., 2002).

A novel method to minimize the damage to bull ejaculated spermatozoa was obtained by coating spermatozoa with the commercial diluents supplemented with egg yolk within 5 min of sperm collection (De Pauw et al., 2003). With this method, the contact between spermatozoa and seminal plasma was limited by collecting bull spermatozoa in a tube that contained diluents supplemented with egg yolk (De Pauw et al., 2003) and the scavenging of BSP proteins by low-density lipoprotein fraction (LDF) contents of egg yolk protects sperm by preventing lipid loss (cholesterol and choline phospholipid) from the sperm membrane (Bergeron et al., 2004).

There is a contradiction in this method that seminal plasma can help sperm cryopreservation and storage or not. Some researchers believe the beneficial effects of seminal plasma (Graham, 1994; Maxwell and Watson, 1996) and others the harmful effects (De Pauw et al., 2003; Roostaei-Ali Mehr et al., 2015; García et al. 2017). This contradictory in regards to removal of the seminal plasma perior to sperm preservation which could improve the motility, viability and plasma membrane integrity of liquid stored ram spermatozoa or not, cause the need of more investigation on it. Therefore, the objective of the present study was to investigate the effect of different levels of seminal plasma and cold-shock on ram spermatozoa during $36 \mathrm{~h}$ of storage at $5^{\circ} \mathrm{C}$.

\section{Materials and Methods}

\section{Chemical reagents}

The following chemicals were used: tris[hydroxymethyl]aminomethane, citric acid monohydrate, glucose, fructose and sodium citrate dihydrate (AppliChem $\mathrm{GmbH}$, Darmstadt, Germany), nigrosin (Merck, Darmstadt, Germany) and eosin (Panreac, EU, Spain).

\section{Animals}

The study was performed on four Taleshi rams aged between 3 to 5 years. The animals were kept at the University of Guilan, Faculty of Agricultural Sciences, Education Research and Practice Farm, South of Rasht (it is located at $37^{\circ} 12^{\prime}$ North latitude and $49^{\circ} 39^{\prime}$ longitude) under uniform housing and lighting conditions. The rams were fed daily with a diet providing $100 \%$ 
of their nutritional needs (NRC, 1985). Animals had free access to salt lick and fresh water. All experimental procedures were performed under the supervision of the Ethics Committee of the University of Guilan.

\section{Semen collection, dilution and storing}

\section{Experiment 1}

Semen was collected by an artificial vagina from four rams four times at two-day intervals (De Pauw et al., 2003), during the breeding season from autumn to early winter. Within 5 min, the second ejaculates as coated spermatozoa (CS) were collected following the uncoated spermatozoa, using the same method but in a tube containing $1 \mathrm{~mL}$ Tris-glucose diluent containing $15 \%$ egg yolk. After collection, both samples were transported to the laboratory in an insulated Styrofoam box $\left(33^{\circ} \mathrm{C}\right)$ within 45 min after collection.

First and second ejaculates were within the criteria of $>0.5 \mathrm{~mL}$ in volume, sperm with $>70 \%$ motility and a concentration higher than $2.5 \times 10^{9}$ sperm $/ \mathrm{mL}$ were pooled seperately. Uncoated spermatozoa were split into four aliquots and diluted with Tris-glucose diluent containing egg yolk (resulting in final concentrations of egg yolk $=15 \%$ and sperm $=600 \times 10^{6} \mathrm{cell} / \mathrm{sL}$ ). Then, half of aliquots (cold-shock) were suddenly put on ice water for $15 \mathrm{~min}$ and other (non- cold shock) was gradually $\left(0.25^{\circ} \mathrm{C} / \mathrm{min}\right.$ ) chilled by Test Chamber (EG53AH, KATO, Japan) to $5^{\circ} \mathrm{C}$ (Rajabi-Toustani et al., 2014). The procedure explained was repeated four times (Figure 1a).

Immediately after primary assessment, CS were pooled and centrifuged for $10 \mathrm{~min}$ at $720 \times \mathrm{g}$ at room temperature (RT) to remove the supernatant. CS were split in four fractions and each fraction divided in three aliquots $\left(1200 \times 10^{6} \mathrm{sperm} / \mathrm{mL}\right)$ and $0 \%$ SP (seminal plasma) $+100 \%$ Tris-glucose diluent $\left(\mathrm{CS}_{0 \% \mathrm{sP}}\right), 50 \% \mathrm{SP}+50 \%$ Tris-glucose diluent $\left(\mathrm{CS}_{50 \% \mathrm{sP}}\right)$ and $100 \% \mathrm{SP}+0 \%$ Trisglucose diluent $\left(\mathrm{CS}_{100 \% \mathrm{sP}}\right)$, added respectively, based on ram spermatocrit (32\%) as previously reported (Roostaei-Ali Mehr and Sharafi, 2013) and incubated for 15 min at RT. At last each aliquot was diluted 1:1 (v:v) with Tris-glucose diluent containing 30\% egg yolk (resulting in final concentrations of egg yolk $=15 \%$ and sperm $=600 \times 10^{6} \mathrm{cell} / \mathrm{s} / \mathrm{mL}$ ). Then half of aliquots (coldshock) were suddenly put on ice water for $15 \mathrm{~min}$ and another (non-cold shock) was gradually $\left(0.25^{\circ} \mathrm{C} / \mathrm{min}\right)$ chilled by Test Chamber (EG53AH, KATO, Japan) to $5^{\circ} \mathrm{C}$ (Rajabi-Toustani et al., 2014). This procedure was repeated four times ( $r=4$; Figure $1 \mathrm{~b})$.

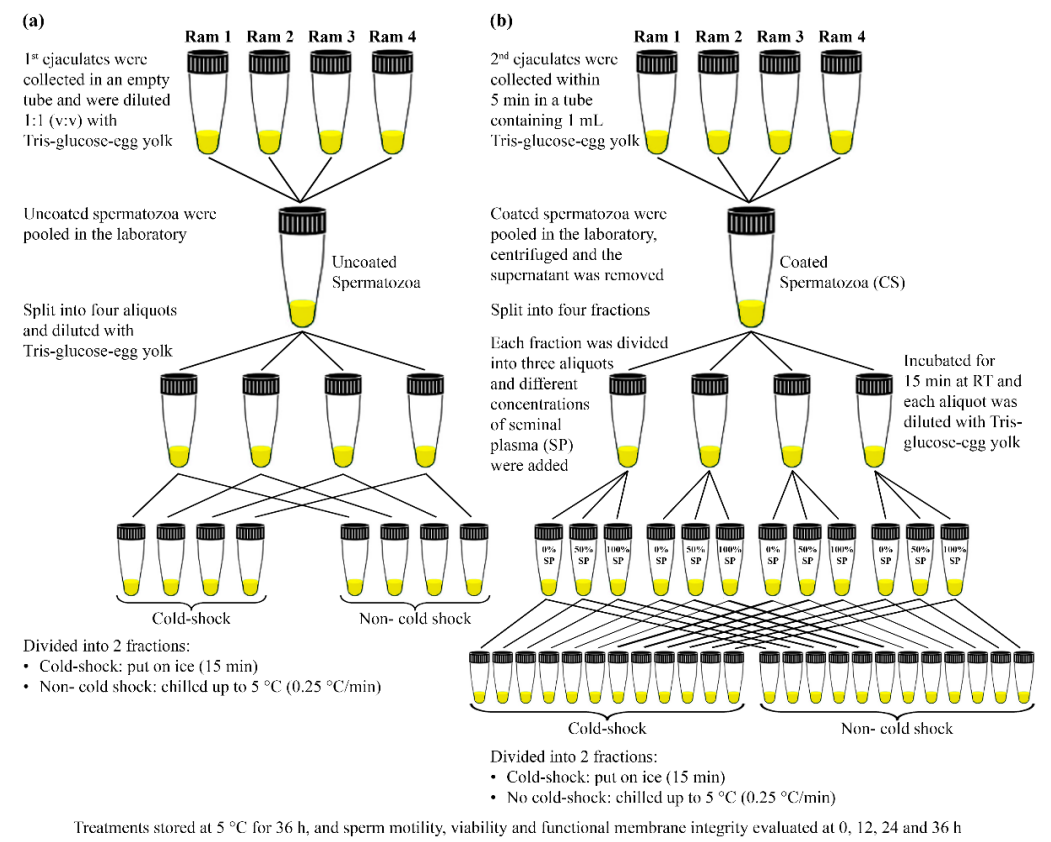

Figure 1. Schematic diagram of the sample preparation procedure in Experiment 1. 


\section{Experiment 2}

The testes were surgically isolated by open castration under local anesthesia from three rams by a veterinarian. After isolation, the testes were placed in sterile plastic containers, including sterile isotonic normal saline at $35^{\circ} \mathrm{C}$, and transported to the laboratory, and mature ram epididymal spermatozoa (EPS) were extracted from the cauda segment of the epididymis within $2 \mathrm{~h}$ after surgery. Cauda epididymides were cut with a scalpel into small pieces and were suspended in a Petri dish containing $5 \mathrm{ml}$ Tris-glucose diluent for $15 \mathrm{~min}$. To limit contamination, epididymis samples were carefully dissected free of blood clots and extraneous tissues. Care was taken not to cut blood vessels (Kaabi et al., 2003; Roostaei Ali-Mehr et al., 2012). After that, the sperm suspension was pooled and sedimented by centrifugation at $700 \times \mathrm{g}$ for $10 \mathrm{~min}$ at room temperature (RT). This spermatozoa preparation was used for the experiment (Figure 2).

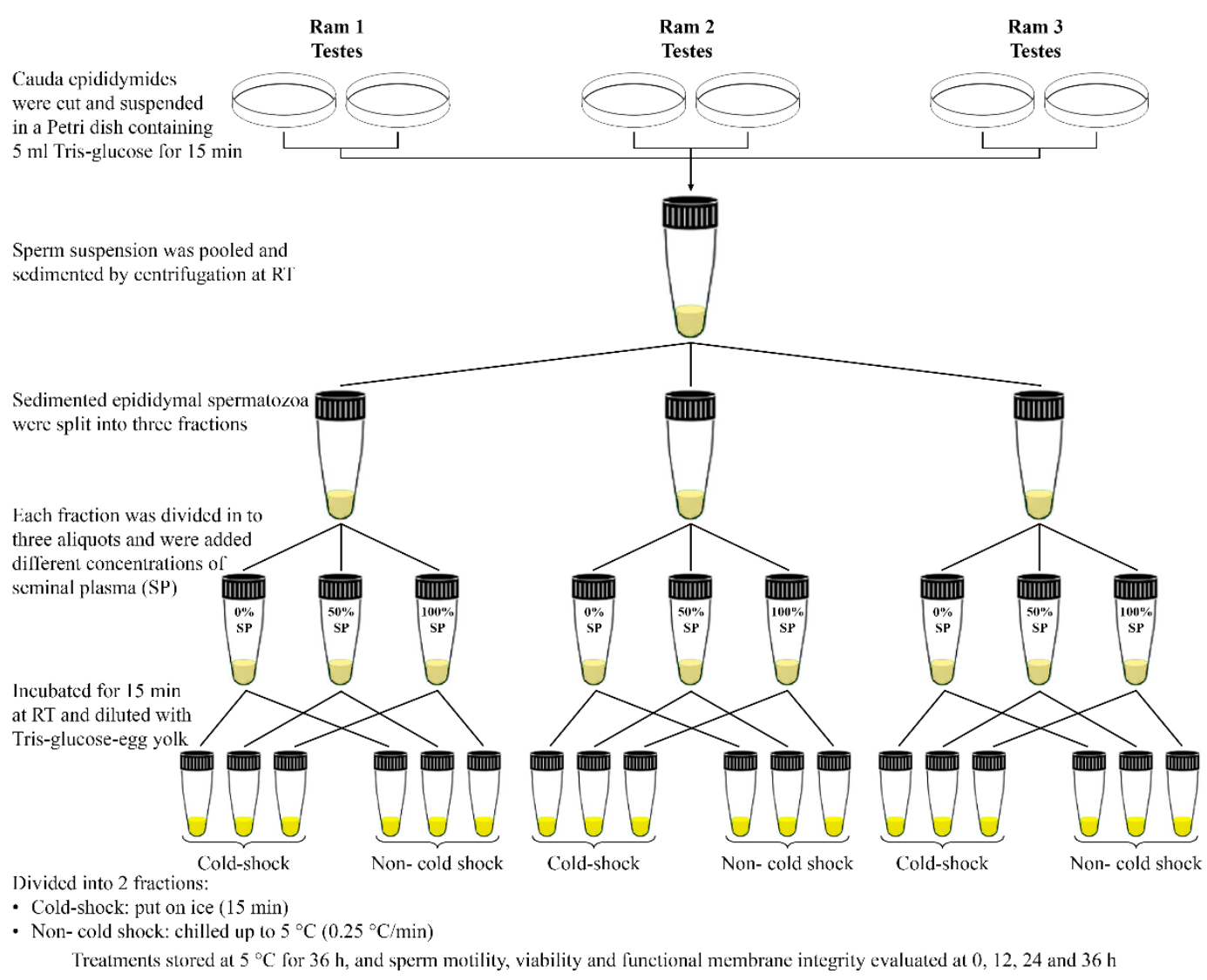

Figure 2. Schematic diagram of the sample preparation procedure in Experiment 2 .

Epididymal spermatozoa were split in three fractions and each fraction divided in three aliquots $\left(1200 \times 10^{6} \mathrm{sperm} / \mathrm{mL}\right)$ and $0 \% \mathrm{SP}+100 \%$ Tris-glucose diluent $\left(\mathrm{EpS}_{0 \% \mathrm{SP}}\right), 50 \% \mathrm{SP}+50 \%$ Tris-glucose diluent $\left(\mathrm{EPS}_{50 \% \mathrm{SP}}\right)$ and $100 \% \mathrm{SP}+0 \%$ Tris-glucose diluent $\left(\mathrm{EPS}_{100 \% \mathrm{SP}}\right)$, added respectively, and incubated for $15 \mathrm{~min}$ at RT. At last, each aliquot was diluted 1:1 (v:v) with Trisglucose diluent containing 30\% egg yolk (resulting in final concentrations of egg yolk $=15 \%$ and sperm $=600 \times 10^{6} \mathrm{cells} / \mathrm{ml}$ ). Then aliquots were placed under cold-shock and non- cold shock conditions as described in Experiment 1 (Figure 2).

Aliquots of experiments 1 and 2 were kept at $5^{\circ} \mathrm{C}$ up to $36 \mathrm{~h}$ and sperm motility, viability and functional membrane integrity were determined at $0,12,24$ and $36 \mathrm{~h}$ within storage (Figure 2). 


\section{Seminal plasma preparation}

For both experiments, ejaculates from four rams were collected, centrifuged (6500 $\mathrm{xg}$ for $15 \mathrm{~min}$ at $4^{\circ} \mathrm{C}$ ) and the clear supernatant was recovered. Seminal plasma were pooled, filtered $\left(0.22 \mu \mathrm{m}\right.$ filter) and stored in $1 \mathrm{~mL}$ aliquots at $-20^{\circ} \mathrm{C}$. Samples were thawed at RT prior to use.

\section{Sperm assessment}

The concentration of spermatozoa was determined by means of a Neubauer haemocytometer.

The percentage of sperm motility was assessed subjectively by phase-contrast microscopy (400x) on a warm stage at $37^{\circ} \mathrm{C}$ (Evans et al., 1987).

The viability was assessed by means of a one-step eosin-nigrosin staining (Björndahl et al., 2003). Briefly, equal volumes of semen and stain solution ( $0.67 \mathrm{~g}$ eosin $Y, 0.9 \mathrm{~g}$ sodium chloride and $10 \mathrm{~g}$ nigrosin in $100 \mathrm{~mL}$ distilled water) were incubated for $30 \mathrm{~s}$ at $\mathrm{RT}\left(22^{\circ} \mathrm{C}\right)$. One drop of mixture was put on a slide, instantly smeared and air dried. A total of 200 sperm were evaluated under light microscope (1000× magnification, oil immersion). Sperm showing partial or complete pink or red colour was considered dead, and sperm showing strict exclusion of the stain was considered to be alive.

The hypo-osmotic swelling test (HOST) was used to evaluate the functional integrity of the sperm membrane. The procedure was described by Jeyendran et al. (1992) and adapted for ram semen by García-Artiga (1994). HOST was performed by incubating $5 \mu \mathrm{l}$ of semen with $500 \mu \mathrm{l}$ of a $100 \mathrm{mOsm}$ hypo-osmotic solution ( $7.35 \mathrm{~g}$ sodium citrate dihydrate and $13.51 \mathrm{~g}$ fructose in $1 \mathrm{~L}$ distilled water) at $37^{\circ} \mathrm{C}$ for $30 \mathrm{~min}$. One drop of the mixture was placed on a prewarmed slide, covered with a cover slip and examined under a phase-contrast microscope (400x magnification). The sperm with swollen tails were considered intact. To assess the percentages of intact sperm, a total of 200 sperm were evaluated in at least five different microscopic fields.

\section{Statistical analysis}

All data on motility, viability and functional membrane integrity of sperm were recorded after $0,12,24$ and $36 \mathrm{~h}$ storage at $5^{\circ} \mathrm{C}$ and analyzed as repeated measures data of GLM procedure of SAS (SAS Institute Inc., 2002) based on completely randomized design. There were four (Uncoated spermatozoa, $\mathrm{CS}_{0 \%} \mathrm{SP}, \mathrm{CS}_{50 \% \mathrm{SP}}$ and $\mathrm{CS}_{100 \% \mathrm{SP}}$ ) and three $\left(\mathrm{EPS}_{0 \% \mathrm{SP}}\right.$, $\mathrm{EpS}_{50 \% \mathrm{SP}}$ and $\mathrm{EpS}_{100 \% \mathrm{sP}}$ ) treatments in experiment 1 and 2, respectively. Four times of storage was used as repeated measure. Results are reported as means \pm SE. The significance of differences between means was tested at $P<0.05$ by Duncan's multiple range tests.

\section{Results}

\section{Experiment 1}

Under the non- cold shock condition, coated spermatozoa treated with 0\% SP showed the higher motility compared to uncoated spermatozoa after 12,24 and $36 \mathrm{~h}$ of storage at $5^{\circ} \mathrm{C}$ $(P<0.05$; Figure 3$)$. There was no difference between the coated spermatozoa treated with 0 and $50 \%$ SP in the percentage of sperm motility $(P>0.05)$ at 0,24 and $36 \mathrm{~h}$ of storage $(P<0.05)$ respectively. No difference in motility was observed between the coated spermatozoa treated with 50 and $100 \%$ SP and the uncoated spermatozoa during $36 \mathrm{~h}$ of storage $(P>0.05)$. The coated spermatozoa treated with 0 and $50 \%$ SP showed the highest viability compared to uncoated spermatozoa after 12,24 and 36 h of storage ( $P<0.05$; Figure 3 ). There was difference between coated spermatozoa treated with 0 and $50 \%$ SP in the percentage of sperm viability at $0 \mathrm{~h}$ of storage $(P<0.05)$. Uncoated spermatozoa showed the lowest viability compared to other treatments at $36 \mathrm{~h}$ of storage $(P<0.05)$. 


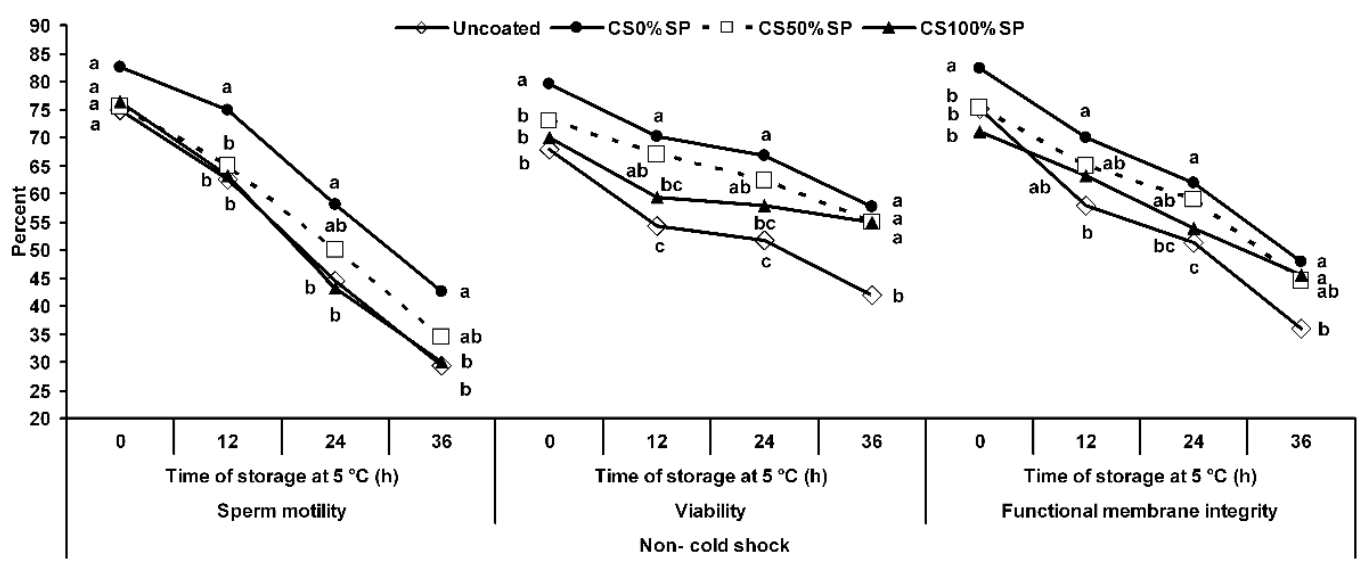

Figure 3. Percentage of motility, viability and functional membrane integrity of ram uncoated $(\diamond)$ and coated spermatozoa treated with $0(\bullet), 50(-\square-)$ or $100 \%(\boldsymbol{\Delta})$ seminal plasma under non- cold shock conditions during incubation at $5{ }^{\circ} \mathrm{C}$ for $36 \mathrm{~h}$. ${ }^{\text {acc }}$ Different superscripts indicate significant differences among treatments at each time of storage $(P<0.05)$.

Functional membrane integrity of non- cold shock samples was higher in the coated spermatozoa treated with $0 \% \mathrm{SP}$ compared to uncoated spermatozoa during $36 \mathrm{~h}$ of storage $(P<0.05$; Figure 3).

Under cold-shock conditions, coated spermatozoa treated with 0\% SP showed the highest motility compared to uncoated spermatozoa during $36 \mathrm{~h}$ of storage $(P<0.05)$; however, no difference was observed between the coated spermatozoa treated with 0 and $50 \% \mathrm{SP}(P>0.05)$ at 12,24 and $36 \mathrm{~h}$ of storage, respectively ( $P<0.05$; Figure 4$)$. There were no differences among the uncoated and the coated spermatozoa treated with 50 and $100 \%$ SP in regards to the percentage of sperm motility at 0,24 and $36 \mathrm{~h}$ of storage $(P>0.05)$.

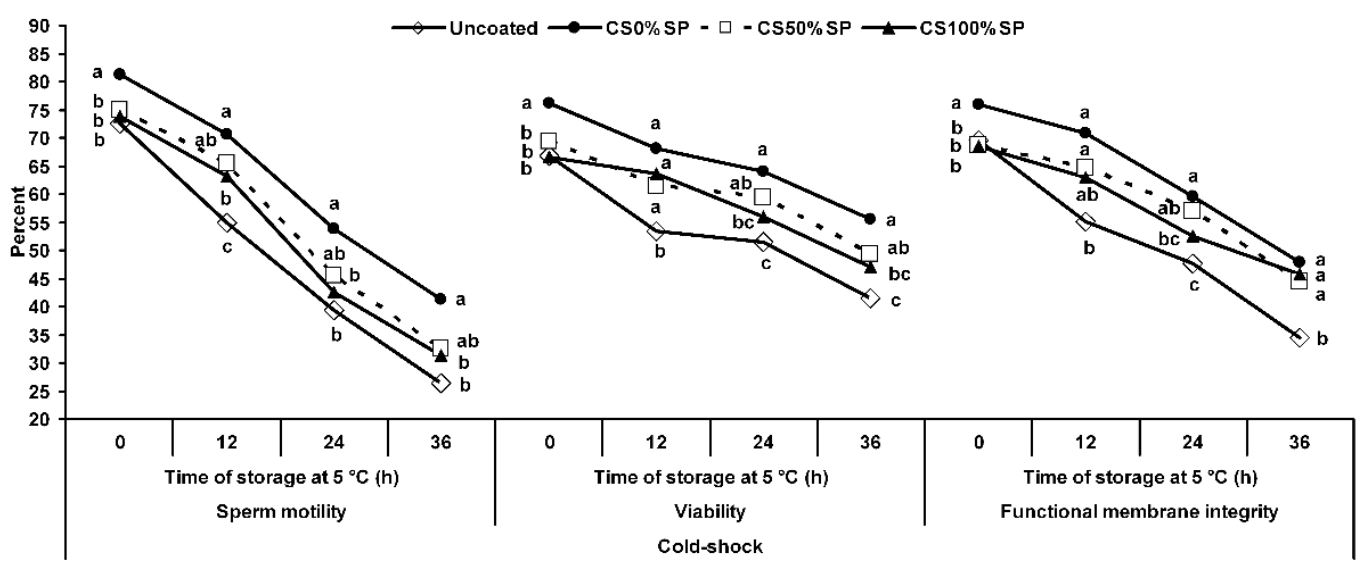

Figure 4. Percentage of motility, viability and functional membrane integrity of ram uncoated $(\diamond)$ and coated spermatozoa treated with $0(\bullet), 50(-\square-)$ or $100 \%$ ( $\Delta$ ) seminal plasma under cold-shock conditions during incubation at $5{ }^{\circ} \mathrm{C}$ for $36 \mathrm{~h} .{ }^{\mathrm{a}-\mathrm{c}}$ Different superscripts indicate significant differences among treatments at each time of storage $(P<0.05)$.

When spermatozoa were placed under cold-shock conditions, the percentage of viability of coated spermatozoa treated with 0\% SP was higher than uncoated spermatozoa during $36 \mathrm{~h}$ of storage at $5^{\circ} \mathrm{C}(P<0.05$; Figure 4$)$. No difference was observed between coated spermatozoa treated with $100 \%$ SP and uncoated spermatozoa after 0,24 and $36 \mathrm{~h}$ of storage $(P>0.05)$.

Under cold-shock conditions, coated spermatozoa treated with $0 \%$ SP showed the highest functional membrane integrity during the whole period of storage ( $P<0.05$; Figure 4). Uncoated spermatozoa showed the lowest functional membrane integrity compared to the other treatments after $36 \mathrm{~h}$ of storage $(P<0.05)$. 


\section{Experiment 2}

Under the non- cold shock condition, the percentage of motility of epididymal spermatozoa stored with $0 \%$ SP was higher than those with $100 \%$ SP after 24 and 36 h of storage $(P<0.05)$. However, no difference was observed between the epididymal spermatozoa treated with 0 and 50\% SP ( $P>0.05$; Figure 5).

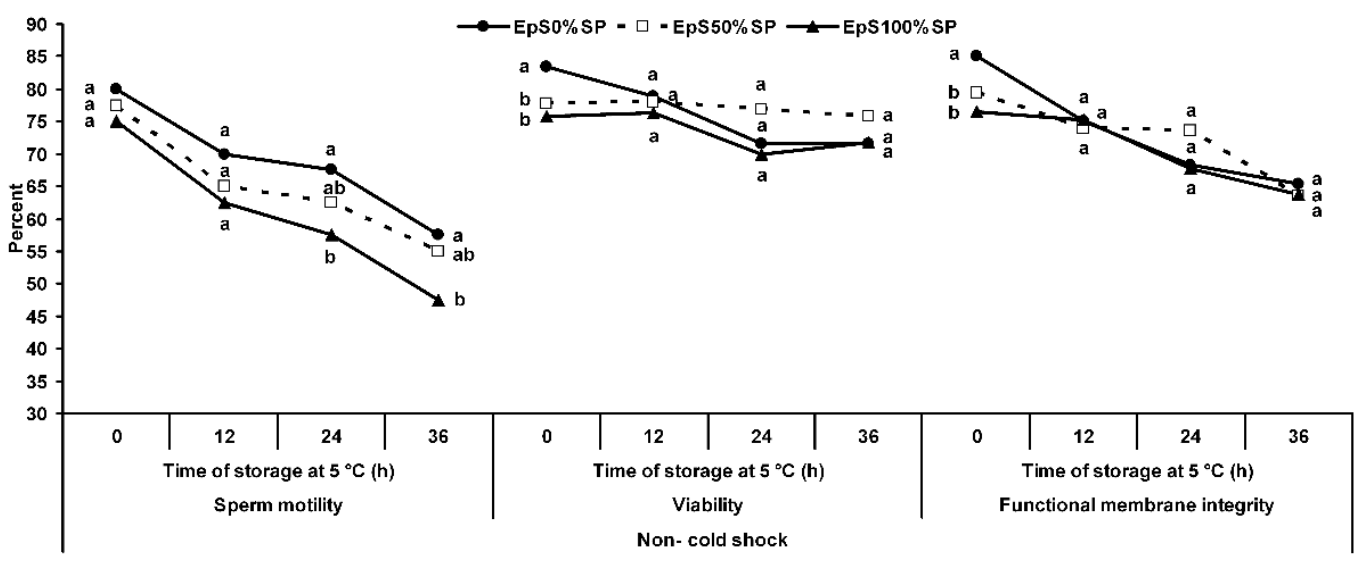

Figure 5. Percentage of motility, viability and functional membrane integrity of ram epididymal spermatozoa treated with $0(\bullet), 50(-\square-)$ or $100 \%$ ( $\mathbf{\Delta}$ ) seminal plasma under non- cold shock conditions during incubation at $5{ }^{\circ} \mathrm{C}$ for $36 \mathrm{~h}$. ${ }^{\mathrm{a}-\mathrm{b}}$ Different superscripts indicate significant differences among treatments at each time of storage $(P<0.05)$.

Under non- cold shock conditions, no difference was observed between the treatments in the percentage of viability and functional membrane integrity $(P>0.05)$ except at $0 \mathrm{~h}$ of storage, when epididymal spermatozoa treated with $0 \%$ SP showed the highest viability and functional membrane integrity $(P<0.05$; Figure 5).

Under cold-shock conditions, epididymal spermatozoa treated with $0 \%$ SP showed the highest motility and viability at $0 \mathrm{~h}$ of storage $(P<0.05$; Figure 6$)$. No difference was observed between the epididymal spermatozoa treated with 0 and 50\% SP in the percentage of motility and viability after 36 and $24 \mathrm{~h}$ of storage, respectively $(P>0.05)$.

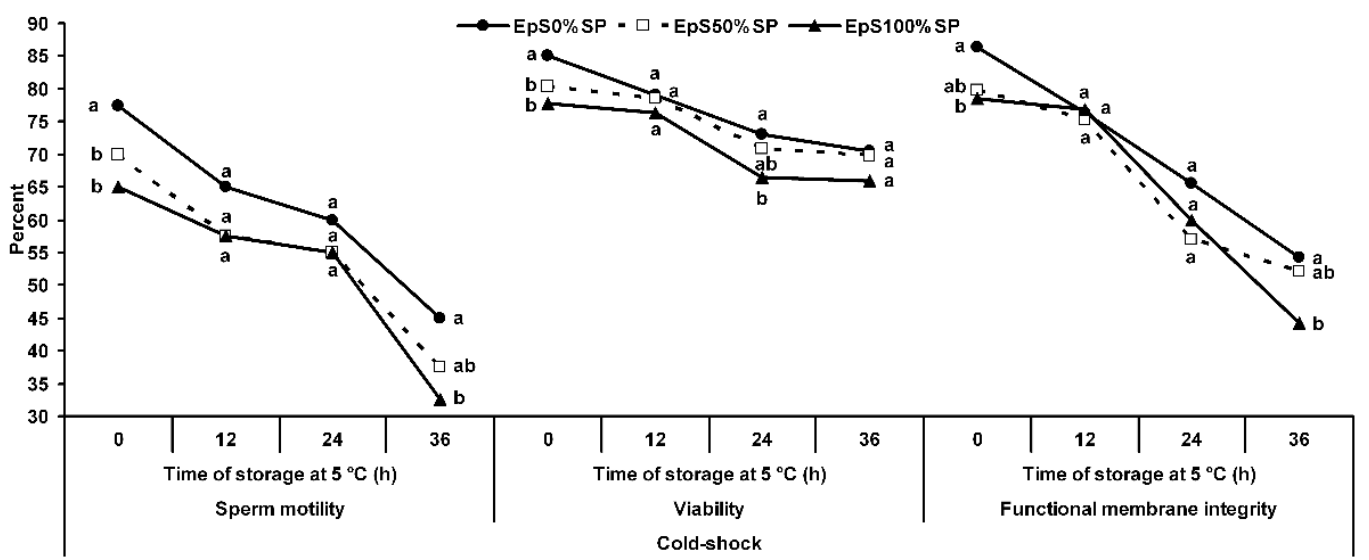

Figure 6. Percentage of motility, viability and functional membrane integrity of ram epididymal spermatozoa treated with $0(\bullet), 50(-\square-)$ or $100 \%$ ( $\mathbf{\Delta}$ ) seminal plasma under cold-shock conditions during incubation at $5{ }^{\circ} \mathrm{C}$ for $36 \mathrm{~h}$. ${ }^{\mathrm{a}-\mathrm{b}}$ Different superscripts indicate significant differences among treatments at each time of storage $(P<0.05)$.

When epididymal spermatozoa were placed under cold-shock conditions, the percentage of functional membrane integrity of spermatozoa treated with $0 \%$ SP was significantly $(P<0.05)$ higher than that with $100 \%$ SP after 0 and $36 \mathrm{~h}$ of storage $(P<0.05)$. No difference was observed between the epididymal spermatozoa treated with 0 and 50\% SP ( $P>0.05$; Figure 6$)$. 


\section{Discussion}

The results of the present study suggested that removal of seminal plasma or reducing the time that the spermatozoa were exposed to seminal plasma increases survival of liquid stored ram semen at $5^{\circ} \mathrm{C}$; however, seminal plasma serves as a vehicle for ejaculated sperm, and contains the various proteins and polypeptides that their functions are poorly understood (Manjunath and Thérien, 2002).

Regards of being in non- cold shock or cold-shock conditions, motility, viability and functional membrane integrity was higher in the coated spermatozoa treated with $0 \%$ SP than the uncoated spermatozoa during $36 \mathrm{~h}$ storage at $5^{\circ} \mathrm{C}$. Coated spermatozoa treated with $0 \%$ SP had minimum proximity of the spermatozoa and seminal plasma compared to other treatments. Seminal plasma heparin-binding proteins are believed to attach themselves to the sperm surface, especially to the lipids containing a phosphorylcholine group (Calvete et al., 1997), thus allowing heparin-like glycosaminoglycans in the female to trigger sperm capacitation (Nass et al., 1990; Martins et al., 2013). On the other hand, bovine seminal fluid also contains a variety of BSP proteins that bind to phospholipids on the sperm cell membrane, thus modulating the changes that spermatozoa undergo during capacitation (Desnoyers and Manjunath, 1992; Thérien et al., 1995).

The results of the present study agree with findings by De Pauw et al. (2003) that showed that prolonged exposure of spermatozoa to seminal plasma reduces both liquid stored sperm motility and viability and permanently diminishes their fertilizing capacity. Therefore, it is essential that seminal plasma is removed quickly and efficiently. Washing spermatozoa by centrifugal sedimentation and resuspension in fresh medium is generally held as the quickest and most effective method of removing seminal plasma (De Pauw et al., 2003). Our results confirm that detrimental effects of seminal plasma can decrease by reduction of (up to 50\%) its concentration.

García et al. (2017) recently shown, sperm washing by centrifugation provided a beneficial effect on ram sperm cryopreservation as seen in sperm viability, membrane integrity and most of the kinetic parameters after thawing. However, the cause for this higher survival could be due to various reasons. One reason may be that the removal of seminal plasma from cryopreservation extenders could improve the protective capacity of the egg yolk against the cold shock as described in different species like rabbit (Ritar and Salamon, 1991), buck (Aboagla and Terada, 2003; Bispo et al., 2011), boar (Bathgate et al., 2006) or horse (Martin et al., 1979), suggesting a negative interaction between seminal plasma and egg yolk, thus affecting motility. Another explanation could be that the technique used to separate seminal plasma through centrifugation may also have eliminated a high percentage of damaged and dead sperm cells (Cebrián et al., 2010).

Spermatozoa recovered from epididymides have suffered the lowest effects of seminal plasma components. As our results showed, the motility of epididymal spermatozoa treated with $0 \%$ SP and gradually chilled was higher than $100 \%$ SP after 24 and $36 \mathrm{~h}$ of storage at $5^{\circ} \mathrm{C}$. Epididymal spermatozoa have minimum proximity to seminal plasma and there was no significant difference observed between the treatments in most parameters and different storage times. Other studies have shown that seminal plasma proteins induce the cholesterol efflux of epididymal sperm membrane in bulls (Thérien et al., 1998), boars (Lusignan et al., 2007) and rams (Roostaei-Ali Mehr et al., 2015). BSP protein alone was capable of stimulating cholesterol efflux from bull epididymal sperm in a dose- and time-dependent manner. During the initial 15-30 min of exposure, 7-15\% cholesterol was removed, and further exposure of sperm for up to $4 \mathrm{~h}$ resulted in about 25\% cholesterol removal (Manjunath and Thérien, 2002). Thus long exposure of sperm to these proteins or exposure to large concentrations of them could be deleterious to the sperm membrane and storage. In addition, sperm from species with a low level of cholesterol in their sperm membrane have a decreased tolerance to coldshock as compared to those with a high level of cholesterol (Darin-Bennett and White, 1977; Drobnis et al., 1993).

In this experiment, the contact time between seminal plasma and spermatozoa was limited by collecting and diluting ram semen directly in Tris-glucose diluent supplemented with egg 
yolk. Egg yolk is widely used in preservation media, employed for storage of semen from domestic, farm, and zoo animals including endangered species. Phospholipids present in LDL of egg yolk protect sperm by forming a protective film on the sperm surface (Quinn et al., 1980) or by replacing sperm membrane phospholipids that are lost or damaged during the cryopreservation process (Foulkes et al., 1980; Graham and Foote, 1987). Also LDL competes with detrimental seminal plasma cationic peptides $(<5 \mathrm{kDa})$ in binding to the sperm membrane and thus protects the sperm (Vishwanath et al., 1992). On the other hand, milk reduces BSP binding to goat sperm, and such events may explain the protective effect of milk during goat sperm preservation (de Menezes et al., 2016).

While some authors remark the importance of the seminal plasma in the preservation of motility and viability in ram thawed sperm (Graham, 1994; Maxwell and Watson, 1996; van Tilburg et al., 2021) and the importance of seminal plasma heparin-affinity proteins for the success of fertilization (Martins et al., 2013), other researchers describe harmful effects (Schmehl et al., 1986). Detrimental effects of seminal plasma on motility of liquid stored (Lamirande et al., 1984; Dott et al., 1979; Iwamoto et al., 1993) and frozen-thawed (Roostaei-Ali Mehr and Sharafi, 2013) sperm and viability of liquid stored (Dott et al., 1979) and frozenthawed (Garcia and Graham, 1987; Roostaei-Ali Mehr and Sharafi, 2013) sperm have been reported. These results are similar to our findings that state that the removal of seminal plasma causes beneficial effects on spermatozoa, and results obtained from epididymal spermatozoa are an affirmation of these conclusions. Our results indicated that the coated spermatozoa are better than uncoated spermatozoa and the removal of seminal plasma had a good effect on motility, viability and plasma membrane integrity of ram spermatozoa.

\section{Conclusion}

Seminal plasma act like a double-edged sword being both beneficial and detrimental to sperm depending on different factors such as the concentration and duration of exposure and it requires further research. In conclusion, removal of seminal plasma and/or reduction of (up to $50 \%$ ) its concentration can decrease the detrimental effects of seminal plasma on chilled ram spermatozoa.

\section{Acknowledgements}

The authors wish to thank Prof. Dr. Tetsuma Murase (Laboratory of Theriogenology, Department of Veterinary Medicine, Faculty of Applied Biological Sciences, Gifu University, Japan) for his valuable help in revising the manuscript.

\section{References}

Aboagla EME, Terada T. Trehalose-enhanced fluidity of the goat sperm membrane and its protection during freezing. Biol Reprod. 2003;69(4):1245-50. http://dx.doi.org/10.1095/biolreprod.103.017889. PMid:12801983.

Bathgate R, Maxwell W, Evans G. Studies on the effect of supplementing boar semen cryopreservation media with different avian egg yolk types on in vitro post-thaw sperm quality. Reprod Domest Anim. 2006;41(1):68-73. http://dx.doi.org/10.1111/j.1439-0531.2006.00623.x. PMid:16420332.

Bergeron A, Crête MH, Brindle Y, Manjunath P. Low-density lipoprotein fraction from hen's egg yolk decreases the binding of the major proteins of bovine seminal plasma to sperm and prevents lipid efflux from the sperm membrane. Biol Reprod. 2004;70(3):708-17. http://dx.doi.org/10.1095/biolreprod.103.022996. PMid:14613896.

Bispo CAS, Pugliesi G, Galvão P, Rodrigues MT, Ker PG, Filgueiras B, Carvalho GR. Effect of low and high egg yolk concentrations in the semen extender for goat semen cryopreservation. Small Rumin Res. 2011;100(1):54-8. http://dx.doi.org/10.1016/j.smallrumres.2011.05.003.

Björndahl L, Söderlund I, Kvist U. Evaluation of the one-step eosin-nigrosin staining technique for human sperm vitality assessment. Hum Reprod. 2003;18(4):813-6. http://dx.doi.org/10.1093/humrep/deg199. PMid:12660276. 
Bogart R, Mayer DT. The effects of egg yolk on the various physical and chemical factors detrimental to spermatozoan viability. J Anim Sci. 1950;9(2):143-52. http://dx.doi.org/10.2527/jas1950.92143x. PMid:15415361.

Calvete JJ, Raida M, Gentzel M, Urbanke C, Sanz L, Töpfer-Petersen E. Isolation and characterization of heparin- and phosphorylcholine-binding proteins of boar and stallion seminal plasma: primary structure of porcine pB1. FEBS Lett. 1997;407(2):201-6. http://dx.doi.org/10.1016/S00145793(97)00344-X. PMid:9166899.

Cebrián J, Muiño-Blanco T, Pérez-Pé RCA. Manejo y conservación del semen. In: Abecia Martínez A, Forcada Miranda F, editors. Manejo reproductivo en ganado ovino. Zaragoza, Spain: Editorial Servet; 2010.

Darin-Bennett A, White IG. Influence of the cholesterol content of mammalian spermatozoa on susceptibility to cold-shock. Cryobiology. 1977;14(4):466-70. http://dx.doi.org/10.1016/00112240(77)90008-6. PMid:560945.

de Menezes EB, van Tilburg M, Plante G, de Oliveira RV, Moura AA, Manjunath P. Milk proteins interact with goat Binder of SPerm (BSP) proteins and decrease their binding to sperm. Cell Tissue Res. 2016;366(2):427-42. http://dx.doi.org/10.1007/s00441-016-2438-2. PMid:27432314.

De Pauw IM, Van Soom A, Maes D, Verberckmoes S, de Kruif A. Effect of sperm coating on the survival and penetrating ability of in vitro stored bovine spermatozoa. Theriogenology. 2003;59(5-6):1109-22. http://dx.doi.org/10.1016/S0093-691X(02)01186-X. PMid:12527060.

Desnoyers L, Manjunath P. Major proteins of bovine seminal plasma exhibit novel interactions with phospholipid. J Biol Chem. 1992;267(14):10149-55. http://dx.doi.org/10.1016/S0021-9258(19)50212-5. PMid:1577785.

Dott HM, Harrison RA, Foster GC. The maintenance of motility and the surface properties of epididymal spermatozoa from bull, rabbit and ram in homologous seminal and epididymal plasma. J Reprod Fertil. 1979;55(1):113-24. http://dx.doi.org/10.1530/jrf.0.0550113. PMid:34036.

Drobnis EZ, Crowe LM, Berger T, Anchordoguy TJ, Overstreet JW, Crowe JH. Cold shock damage is due to lipid phase transitions in cell membranes: A demonstration using sperm as a model. J Exp Zool. 1993;265(4):432-7. http://dx.doi.org/10.1002/jez.1402650413. PMid:8463792.

Evans G, Maxwell WMC, Salamon S. Salamon's artificial insemination of sheep and goats. London: Butterworths; 1987.

Foulkes JA, Sweasey D, Goodey RG. Fertility of bull spermatozoa in egg-yolk diluents of varied lipid fatty acid composition. J Reprod Fertil. 1980;60(1):165-9. http://dx.doi.org/10.1530/jrf.0.0600165. PMid:7431317.

Garcia MA, Graham EF. Effects of low-molecular-weight fractions (LMWF) from milk, egg yolk, and seminal plasma on freezability of bovine spermatozoa. Cryobiology. 1987;24(5):429-36. http://dx.doi.org/10.1016/0011-2240(87)90046-0. PMid:3652723.

García W, Tabarez A, Palomo MJ. Effect of the type of egg yolk, removal of seminal plasma and donor age on ram sperm cryopreservation. Anim Reprod. 2017;14(4):1124-32. http://dx.doi.org/10.21451/19843143-AR916.

García-Artiga C. Test de endósmosisen ovino. In: Proceedings of the 7th International Meeting on Animal Reproduction; 1994; Murcia, Spain. Murcia: Consejería de Agricultura Ganadería y Pesca; 1994. p. 7781.

Gilmore JA, Liu J, Peter AT, Critser JK. Determination of plasma membrane characteristics of boar spermatozoa and their relevance to cryopreservation. Biol Reprod. 1998;58(1):28-36. http://dx.doi.org/10.1095/biolreprod58.1.28. PMid:9472919.

Graham JK, Foote RH. Effect of several lipids, fatty acyl chain length, and degree of unsaturation on the motility of bull spermatozoa after cold shock and freezing. Cryobiology. 1987;24(1):42-52. http://dx.doi.org/10.1016/0011-2240(87)90005-8. PMid:3816287.

Graham JK. Effect of seminal plasma on the motility of epididymal and ejaculated spermatozoa of the ram and bull during the cryopreservation process. Theriogenology. 1994;41(5):1151-62. http://dx.doi.org/10.1016/S0093-691X(05)80037-8. PMid:16727467.

Iwamoto T, Tanaka H, Osada T, Shinagawa T, Osamura Y, Gagnon C. Origin of a sperm motility inhibitor from boar seminal plasma. Mol Reprod Dev. 1993;36(4):475-81. http://dx.doi.org/10.1002/mrd.1080360411. PMid:8305210.

Jeyendran RS, Van der Ven HH, Zaneveld LJ. The hypoosmotic swelling test: an update. Arch Androl. 1992;29(2):105-16. http://dx.doi.org/10.3109/01485019208987714. PMid:1456832. 
Kaabi M, Paz P, Alvarez M, Anel E, Boixo JC, Rouissi H, Herraez P, Anel L. Effect of epididymis handling conditions on the quality of ram spermatozoa recovered post-mortem. Theriogenology. 2003;60(7):1249-59. http://dx.doi.org/10.1016/S0093-691X(03)00139-0. PMid:14511779.

Kawano N, Shimada M, Terada T. Motility and penetration competence of frozen-thawed miniature pig spermatozoa are substantially altered by exposure to seminal plasma before freezing. Theriogenology. 2004;61(2-3):351-64. http://dx.doi.org/10.1016/S0093-691X(03)00218-8. PMid:14662134.

Killen ID, Caffery GJ. Uterine insemination of ewes with the aid of a laparoscope. Aust Vet J. 1982;59(3):95. http://dx.doi.org/10.1111/j.1751-0813.1982.tb02737.x. PMid:6218800.

Lamirande E, Belles-Isles M, Gagnon C. Characteristics of a seminal plasma inhibitor of sperm motility. Ann N Y Acad Sci. 1984;438:125-31. http://dx.doi.org/10.1111/j.1749-6632.1984.tb38281.x. PMid:6242010.

Lasley JF, Mayer DT. A variable physiological factor necessary for the survival of bull spermatozoa. J Anim Sci. 1944;3(2):129-35. http://dx.doi.org/10.2527/jas1944.32129x.

Lusignan MF, Bergeron A, Crête MH, Lazure C, Manjunath P. Induction of epididymal boar sperm capacitation by $\mathrm{PB} 1$ and BSP-A1/-A2 proteins, members of the BSP protein family. Biol Reprod. 2007;76(3):424-32. http://dx.doi.org/10.1095/biolreprod.106.055624. PMid:17123943.

Manjunath P, Nauc V, Bergeron A, Ménard M. Major proteins of bovine seminal plasma bind to the lowdensity lipoprotein fraction of hen's egg yolk. Biol Reprod. 2002;67(4):1250-8. http://dx.doi.org/10.1095/biolreprod67.4.1250. PMid:12297543.

Manjunath $P$, Thérien I. Role of seminal plasma phospholipid-binding proteins in sperm membrane lipid modification that occurs during capacitation. J Reprod Immunol. 2002;53(1-2):109-19. http://dx.doi.org/10.1016/S0165-0378(01)00098-5. PMid:11730909.

Martin JC, Klug E, Günzel AR. Centrifugation of stallion semen and its storage in large volume straws. J Reprod Fertil Suppl. 1979;(27):47-51. PMid:289825.

Martins JAM, Souza CEA, Silva FDA, Cadavid VG, Nogueira FC, Domont GB, Oliveira JTA, Moura AA. Major heparin-binding proteins of the seminal plasma from Morada Nova rams. Small Rumin Res. 2013;113(1):115-27. http://dx.doi.org/10.1016/j.smallrumres.2013.01.005.

Martinus RD, Molan PC, Shannon P. Deleterious effect of seminal plasma in the cryo-preservation of bovine spermatozoa. N Z J Agric Res. 1991;34(3):281-5. http://dx.doi.org/10.1080/00288233.1991.10417666.

Maxwell WM, Salamon S. Liquid storage of ram semen: a review. Reprod Fertil Dev. 1993;5(6):613-38. http://dx.doi.org/10.1071/RD9930613. PMid:9627724.

Maxwell WMC, Mendoza G, White IG. Post-thawing survival of motile ram sperm after isolation by layering on protein columns. Theriogenology. 1984;21(4):601-6. http://dx.doi.org/10.1016/0093691X(84)90445-X. PMid:16725910.

Maxwell WMC, Watson PF. Recent progress in the preservation of ram semen. Anim Reprod Sci. 1996;42(1-4):55-65. http://dx.doi.org/10.1016/0378-4320(96)01544-8.

Mehr MR-A, Mousavi M, Ghadamyari M. Effect of seminal plasma proteins on membrane cholesterol efflux of ram epididymal spermatozoa. Small Rumin Res. 2015;129:88-91. http://dx.doi.org/10.1016/j.smallrumres.2015.06.001.

Moore Al, Squires EL, Graham JK. Effect of seminal plasma on the cryopreservation of equine spermatozoa. Theriogenology. 2005;63(9):2372-81. http://dx.doi.org/10.1016/j.theriogenology.2004.05.032. PMid:15910920.

Muiño-Blanco T, Pérez-Pé R, Cebrián-Pérez J. Seminal Plasma Proteins and Sperm Resistance to Stress. Reprod Domest Anim. 2008;43(Suppl 4):18-31. http://dx.doi.org/10.1111/j.1439-0531.2008.01228.x. PMid:18803753.

Nass SJ, Miller DJ, Winer MA, Ax RL. Male accessory sex glands produce heparin-binding proteins that bind to cauda epididymal spermatozoa and are testosterone dependent. Mol Reprod Dev. 1990;25(3):237-46. http://dx.doi.org/10.1002/mrd.1080250305. PMid:2331373.

National Research Council. Nutrient requirements of sheep. 6th ed. Washington: National Academies Press; 1985.

Phillips PH, Lardy HA. A yolk-buffer pabulum for the preservation of bull semen. J Dairy Sci. 1940;23(5):399-404. http://dx.doi.org/10.3168/jds.S0022-0302(40)95541-2. 
Poiani A. Complexity of seminal fluid: a review. Behav Ecol Sociobiol. 2006;60(3):289-310. http://dx.doi.org/10.1007/s00265-006-0178-0.

Quinn PJ, Chow PY, White IG. Evidence that phospholipid protects ram spermatozoa from cold shock at a plasma membrane site. J Reprod Fertil. 1980;60(2):403-7. http://dx.doi.org/10.1530/jrf.0.0600403. PMid:7431346.

Rajabi-Toustani R, Roostaei-Ali Mehr M, Motamedi-Mojdehi R. Effect of different levels of egg yolk on ram sperm coating and preserving at $5^{\circ} \mathrm{C}$. Iran J Vet Res. 2014;15(2):168-71. http://dx.doi.org/10.22099/IJVR.2014.2366.

Ritar AJ, Salamon S. Effects of month of collection, method of processing, concentration of egg yolk and duration of frozen storage on viability of Angora goat spermatozoa. Small Rumin Res. 1991;4(1):2937. http://dx.doi.org/10.1016/0921-4488(91)90050-Z.

Roostaei Ali-Mehr M, Rajabi-Toustani R, Motamedi-Mojdehi R. Leptin receptor in ram epididymal spermatozoa. Engineering. 2012;4(20B):121-3. http://dx.doi.org/10.4236/eng.2012.410B031.

Roostaei-Ali Mehr M, Sharafi F. The effect of seminal plasma on the quality of coated ram frozen-thawed spermatozoa. Iran J Vet Res. 2013;14:305-12. http://dx.doi.org/10.22099/IJVR.2013.1827.

SAS Institute Inc. SAS® user's guide. Statistics. Cary, NC; 2002.

Schmehl MK, Anderson SP, Vazquez IA, Graham EF. The effect of dialysis of extended ram semen prior to freezing on post-thaw survival and fertility. Cryobiology. 1986;23(5):406-14. http://dx.doi.org/10.1016/0011-2240(86)90025-8. PMid:3769516.

Thérien I, Bleau G, Manjunath P. Phosphatidylcholine-binding proteins of bovine seminal plasma modulate capacitation of spermatozoa by heparin. Biol Reprod. 1995;52(6):1372-9. http://dx.doi.org/10.1095/biolreprod52.6.1372. PMid:7632845.

Thérien I, Moreau R, Manjunath P. Major proteins of bovine seminal plasma and high-density lipoprotein induce cholesterol efflux from epididymal sperm. Biol Reprod. 1998;59(4):768-76. http://dx.doi.org/10.1095/biolreprod59.4.768. PMid:9746724.

van Tilburg M, Sousa S, Lobo MDP, Monteiro-Azevedo ACOM, Azevedo RA, Araújo AA, Moura AA. Mapping the major proteome of reproductive fluids and sperm membranes of rams: from the cauda epididymis to ejaculation. Theriogenology. 2021;159:98-107. http://dx.doi.org/10.1016/j.theriogenology.2020.10.003. PMid:33126182.

Vishwanath R, Shannon P, Curson B. Cationic extracts of egg yolk and their effects on motility, survival and fertilising ability of bull sperm. Anim Reprod Sci. 1992;29(3-4):185-94. http://dx.doi.org/10.1016/0378-4320(92)90032-9.

Watson P. The causes of reduced fertility with cryopreserved semen. Anim Reprod Sci. 2000;60-61:48192. http://dx.doi.org/10.1016/S0378-4320(00)00099-3. PMid:10844218.

Way AL, Killian GJ. Capacitation and induction of the acrosome reaction in bull spermatozoa with norepinephrine. J Androl. 2002;23(3):352-7. http://dx.doi.org/10.1002/J.1939-4640.2002.TB02242.X. PMid:12002437.

\section{Author contributions}

RRT: Conceptualization, Methodology, Formal analysis, Investigation, Data curation, Writing - original draft, Software, Validation, Visualization; MRAM: Conceptualization, Writing - review \& editing, Supervision, Funding acquisition, Validation, Investigation, Project administration; RMM: Conceptualization, Methodology, Formal analysis, Investigation, Data Curation, Writing - review \& editing, Visualization. 